\title{
Digital Learning: Students' Assessment of Webinars and Web Conferences as a Tool for Acquiring Knowledge and Skills
}

\author{
Anna Alexandrovna Basmanova", Yulia Alexandrovna Grunina, Elena Alexandrovna Kargovskaya \\ Faculty of Humanities and Social Sciences, Foreign Languages Department, Peoples' Friendship University of Russia (RUDN \\ University), Moscow, Russia
}

Received August 24, 2020; Revised October 22, 2020; Accepted November 11, 2020

\section{Cite This Paper in the following Citation Styles}

(a): [1] Anna Alexandrovna Basmanova, Yulia Alexandrovna Grunina, Elena Alexandrovna Kargovskaya, "Digital Learning: Students' Assessment of Webinars and Web Conferences as a Tool for Acquiring Knowledge and Skills," Universal Journal of Educational Research, Vol. 8, No. 12, pp. 6960 - 6966, 2020. DOI: 10.13189/ujer.2020.081263.

(b): Anna Alexandrovna Basmanova, Yulia Alexandrovna Grunina, Elena Alexandrovna Kargovskaya (2020). Digital Learning: Students' Assessment of Webinars and Web Conferences as a Tool for Acquiring Knowledge and Skills. Universal Journal of Educational Research, 8(12), 6960 - 6966. DOI: 10.13189/ujer.2020.081263.

Copyright $(2020$ by authors, all rights reserved. Authors agree that this article remains permanently open access under the terms of the Creative Commons Attribution License 4.0 International License

\begin{abstract}
At a stage where the latest information technologies develop rapidly and are integrates into all spheres of human life, higher education institutions are aimed at preparing future Humanities specialists for the work in completely new conditions of the information society. This causes the problem of finding new forms, methods and means of organizing the educational process that will ensure the effective use of information and communication technologies. The purpose of the research is to study the quality of the webinar work of the teachers of the Department of Philosophy through its assessment by students for further improvement, considering the comments and wishes received. In the research, the authors used such theoretical methods as the study of scientific, methodological and pedagogical literature on the problem of using webinars and web conferences as a tool for obtaining knowledge and skills. In order to improve the quality of teaching the discipline "Philosophy" and increase the scientific and methodological level of the application of webinars, considering the opinions of students, a sociological study was conducted. The method of sociological research was a questionnaire survey, in which 51 first-year humanities students of the university took part. Based on the questionnaire of Humanities students, qualitative data have been obtained, such as students' motivation to attend webinars, students' attitudes to the content of webinar materials, students' ideas about
\end{abstract}

the usefulness and appropriateness of webinars and how webinars on Philosophy influence personal, intellectual and professional development of future Humanities specialists.

Keywords Digital Learning, Web Conference, Webinar, Motivation, Quality Assessment

\section{Introduction}

The digital economy creates new products and forms new needs. The speed and volume of obtaining information increase every day [1-3]. At the present stage 0 , more and more attention is paid to digital technologies, including digital learning technologies [4-6].

According to I.K. Ficheman and R. de Deus Lopez, digital learning has four main forms of implementation [7]: 1) e-learning: learning via the Internet using LMS; 2) synchronous e-learning: e-learning with active feedback; 3 ) Internet lectures: the distribution of video lectures using Intranet, social networks and WWW; 4) mobile learning: learning using laptops, smartphones and mobile phones.

A study by S.K. Basak, M. Wotto and P. Belanger [8] analyses fundamental prospects, advantages, disadvantages, and finally, the similarities and differences 
of electronic learning (e-learning), mobile learning (m-learning) and digital learning (d-learning). The authors conclude that e-learning and m-learning are the subsets of d-learning. At the same time, some learning tools can be considered both mobile and electronic [9, 10].

In the definition proposed by O.O. Jethro, A.M. Grace and A.K. Thomas, e-learning refers to the process of generating knowledge, skills and abilities partially or fully through the Internet [11]. Thus, e-learning can be considered to be a form of distance learning. From this point of view, it is distance learning, which is implemented in the Internet environment with the transferring of educational materials in electronic form. This interpretation implies online learning, web-based learning, virtual universities and classes, digital collaboration and technology support for distance learning [12].

In Russian sources, the following interpretation is more common: e-learning is the presentation of educational materials and the management of the learning process using new information and telecommunication technologies [13-15]. We follow the interpretation of e-learning as learning, which is supported and stimulated by the use of information and communication technologies. Thus, in a general sense, e-learning can be considered to be learning that is carried out and supported by electronic means and electronic environments. These electronic means can be either specialized or universal, such as a computer, which belongs to the class of complex electronic devices.

Web-conference, in particular webinar, is one of the tools for acquiring knowledge and skills by future Humanities specialists in digital learning; it is one of the technologies of group interaction between all the participants of educational work, which unites them in a single information environment [16-18].

Web conference functions as an online lesson, offering the opportunity to communicate with a particular audience in real-time through texts typed on the keyboard, as well as through voice and video. Like a classroom lesson, web conference provides visual contact, interactive communication, demonstration of visibility, graphic support for teacher explanations and a survey of the participants [19].

One of the most common technologies for web conferencing using software is webinar, a virtual seminar that is conducted via the Internet; it is possible to communicate with video and audio and to share data with all the participants [20, 21].

The conducted analysis of scientific works showed that the concept of a webinar (from the English web + seminar) requires clarification. The existence of different interpretations of this concept introduced by researchers is explained by the multidimensional nature of didactic aims that they pursued. In particular, while W.P. McKinney considers a webinar to be a virtual seminar organized using Internet technologies [22], R. Polanco-Bueno sees it as a new format of learning, which allows holding classes in real using modern communication technologies that ensure the transmission of audio-visual information. Usually, the teacher holds classes in the lecture mode with the transmission of educational materials. Feedback from students is excluded from the lecture time and takes place in the form of chat or voice communication [23].

According to S.K. Wang and H. Hsu, a webinar is a technology that makes it possible to recreate to the full extent the conditions for a co-organization of learning, namely seminars and laboratory classes, lectures, etc. [24]. M. Power and A. St-Jacques also consider the webinar to be a technology that helps to hold interactive classes in a virtual classroom that provides the necessary functionality for distance collaborative learning for students. Meanwhile, a virtual classroom software is such software that simulates the environment of a real classroom on the Internet [25].

Thus, a webinar is a modern form of learning carried out via the Internet and using special software; it is an interactive, convenient, economically feasible form of communication between the teacher and the student, which rationalizes and optimizes the learning process (and further education).

The progressiveness of webinar technology is in its interactivity, which is the effect of physical presence. Students have the opportunity to perceive everything that the teacher demonstrates and says, to engage in dialogues, to clarify misunderstandings either in verbal or in written form, to answer the posed questions [26].

The study aims at studying the quality of the webinar work of teachers of the Department of Philosophy with the help of the students' assessment for further improvement, taking into account the received comments and suggestions.

Research hypothesis: the students' motivation to participate and attitudes to webinars are generally positive.

According to the results of the study, it can be concluded that the aim was achieved.

\section{Methods}

A set of theoretical and empirical methods was used during the research.

Theoretical methods such as the review of scientific, methodological and pedagogical literature on the problem of using webinars and web conferences as a tool for acquiring knowledge and skills were used.

To improve the quality of teaching Philosophy, in particular and to increase the scientific and methodological level of using webinars, taking into account the students' opinions, the sociological study "The effectiveness of the webinar work of teachers of the Department of Philosophy" was conducted.

The object of the study is full-time first-year students. A total of 51 Humanities students were interviewed (39 
female and 12 male students). The subject of the study is the attitude of the freshmen to webinars on Philosophy and their suggestions regarding possible ways to improve webinar work in the process of teaching Philosophy.

The aims of the research:

- to identify the quality of motivation that encourages students to attend webinars on Philosophy;

- to identify the students' attitude to the content of webinar materials, ideas about the usefulness and appropriateness of webinars and how webinars on Philosophy influence personal, intellectual and professional development of future Humanities specialists.

The questionnaire was chosen to be the research method, taking into account its known advantages: compactness, efficiency, comprehensiveness, informativity.

The questionnaire was developed following generally accepted requirements for the selection of indicators of sociological research (relevance, validity, informativity) and formal rules for constructing questions (unambiguity, brevity, concreteness, certainty, objectivity, accessibility).

The questions were aimed at finding the quantitative indicator of student participation in webinars on philosophy, their reasons for participation/non-participation, goals of participation in webinars, attitude to the quality of the webinars, as well as the effectiveness of webinars in teaching the discipline.

Closed questions (those with a complete list of answer options) were used with nominal and ordinal scales, such as "What (approximate) percentage of philosophy webinars have you listened to?" and "Which (one) of these statements about your reasons for participating or not participating in webinars do you agree with?" Open questions that suggested that the respondents freely express their ideas about the subject of the study were also used. The anonymity of the questionnaire was ensured by the absence of questions with which the identity of the respondent (student) could be identified.

To obtain the most possible objective data, the survey was conducted after the passed examination in Philosophy and before the announcement of its results.

\section{Results}

The results of the questionnaire of students within a sociological study "The effectiveness of the webinar work of teachers of the Department of Philosophy" are presented in Tables 1-5.

Table 1. Distribution of answers to the question "What percentage of webinars on Philosophy (approximately) have you listened to?"

\begin{tabular}{|c|c|c|}
\hline & Quantity & $\%$ \\
\hline $80-100 \%$ (all, almost all) & 32 & $62.7 \%$ \\
\hline $60-80 \%$ & 10 & $19.6 \%$ \\
\hline $40-60 \%$ (about a half) & 5 & $9.8 \%$ \\
\hline $20-40 \%$ & 3 & $5.9 \%$ \\
\hline $\begin{array}{c}0-20 \% \text { (I have not listened at all, I have } \\
\text { hardly listened) }\end{array}$ & 1 & $2.0 \%$ \\
\hline
\end{tabular}

Table 2. Distribution of answers to the question "Which one of these statements about the reasons for your participation or non-participation in webinars do you agree with?"

\begin{tabular}{|c|c|c|}
\hline & Quantity & $\%$ \\
\hline I always participated in webinars & 18 & $35.3 \%$ \\
\hline I missed webinars only for a good reason & 23 & $45.1 \%$ \\
\hline $\begin{array}{c}\text { I participated in webinars when my personal } \\
\text { schedule allowed me }\end{array}$ & 5 & $9.8 \%$ \\
\hline $\begin{array}{c}\text { Mostly, I missed webinars because of } \\
\text { circumstances }\end{array}$ & 4 & $7.8 \%$ \\
\hline $\begin{array}{c}\text { I participated in webinars when I wanted to } \\
\text { participate }\end{array}$ & 1 & $2.0 \%$ \\
\hline Usually, I participated in webinars by accident & - & - \\
\hline
\end{tabular}

Table 3. Distribution of answers to the question "What is your goal when participating in university courses' webinars?" (select 1-2 items from the list, or write an answer)".

\begin{tabular}{|c|c|c|}
\hline & Quantity & $\%$ \\
\hline $\begin{array}{c}\text { I participated in all the webinars regardless the } \\
\text { science, content and interestingness of the course }\end{array}$ & 17 & $33.3 \%$ \\
\hline $\begin{array}{c}\text { My goal is to have the necessary materials for the } \\
\text { exam preparation }\end{array}$ & 22 & $43.1 \%$ \\
\hline $\begin{array}{c}\text { I participate in webinars to get the information } \\
\text { which is not given in the textbook }\end{array}$ & 10 & $19.6 \%$ \\
\hline $\begin{array}{c}\text { I participate in webinars to better understand the } \\
\text { material }\end{array}$ & 19 & $37.3 \%$ \\
\hline I participate in webinars to get an additional mark & 4 & $7.8 \%$ \\
\hline
\end{tabular}

Note: it was possible to give two answers.

Table 4. Distribution of answers to the question "Evaluate the following statements about the level of webinars in Philosophy you have listened to".

\begin{tabular}{|c|c|c|c|c|c|c|c|c|c|c|}
\hline & \multicolumn{2}{|c|}{ Yes } & \multicolumn{2}{|c|}{ Rather yes than no } & \multicolumn{2}{|c|}{ Difficult to answer } & \multicolumn{2}{|c|}{ Rather no than yes } & \multicolumn{2}{|c|}{ No } \\
\hline & Quantity & $\%$ & Quantity & $\%$ & Quantity & $\%$ & Quantity & $\%$ & Quantity & $\%$ \\
\hline Webinars were informative & 28 & $54.9 \%$ & 18 & $35.3 \%$ & 4 & $7.8 \%$ & 1 & $2.0 \%$ & 0 & $0.0 \%$ \\
\hline Webinars were interesting & 16 & $31.4 \%$ & 21 & $41.2 \%$ & 13 & $25.4 \%$ & 1 & $2.0 \%$ & 0 & $0.0 \%$ \\
\hline Webinars were understandable & 19 & $37.3 \%$ & 20 & $39.2 \%$ & 9 & $17.6 \%$ & 3 & $5.9 \%$ & 0 & $0.0 \%$ \\
\hline $\begin{array}{c}\text { I am satisfied with the overall } \\
\text { level of webinars on } \\
\text { Philosophy I listened to }\end{array}$ & 18 & $35.3 \%$ & 22 & $43.1 \%$ & 8 & $15.7 \%$ & 3 & $5.9 \%$ & 0 & $0.0 \%$ \\
\hline
\end{tabular}


Table 5. Distribution of answers to the question "Do you agree with the following statements?"

\begin{tabular}{|c|c|c|c|c|c|c|c|c|c|c|}
\hline $\begin{array}{c}\text { Webinars on Philosophy } \\
\text { helped me .. }\end{array}$ & \multicolumn{2}{|c|}{ Yes } & Rather yes than no & Difficult to answer & \multicolumn{2}{c|}{ Rather no than yes } & \multicolumn{2}{c|}{ No } \\
\cline { 2 - 11 } & Quantity & $\%$ & Quantity & $\%$ & Quantity & $\%$ & Quantity & $\%$ & Quantity & $\%$ \\
\hline $\begin{array}{c}\text { to acquire new knowledge that } \\
\text { will be useful for me in the } \\
\text { future }\end{array}$ & 10 & $19.6 \%$ & 14 & $27.5 \%$ & 18 & $35.3 \%$ & 7 & $13.7 \%$ & 3 & $5.9 \%$ \\
\hline to expand my vocabulary & 16 & $31.4 \%$ & 19 & $37.3 \%$ & 11 & $21.6 \%$ & 4 & $7.8 \%$ & 1 & $2.0 \%$ \\
\hline $\begin{array}{c}\text { to change my understanding of } \\
\text { the concepts that I have used } \\
\text { previously }\end{array}$ & 13 & $25.4 \%$ & 19 & $37.3 \%$ & 12 & $23.5 \%$ & 6 & $11.8 \%$ & 1 & $2.0 \%$ \\
\hline $\begin{array}{c}\text { to better understand cause and } \\
\text { effect of the world around me }\end{array}$ & 10 & $19.6 \%$ & 19 & $37.3 \%$ & 16 & $31.3 \%$ & 5 & $9.8 \%$ & 1 & $2.0 \%$ \\
\hline $\begin{array}{c}\text { to better understand social } \\
\text { processes taking place in the } \\
\text { world }\end{array}$ & 10 & $19.6 \%$ & 19 & $37.3 \%$ & 15 & $29.3 \%$ & 5 & $9.8 \%$ & 2 & $3.9 \%$ \\
\hline $\begin{array}{c}\text { to think in a more disciplined } \\
\text { way (more systematically) }\end{array}$ & 11 & $21.6 \%$ & 20 & $39.2 \%$ & 13 & $25.5 \%$ & 5 & $9.8 \%$ & 2 & $3.9 \%$ \\
\hline $\begin{array}{c}\text { to understand the } \\
\text { methodological importance of } \\
\text { Philosophy in the science } \\
\text { development }\end{array}$ & 12 & $23.5 \%$ & 19 & $37.3 \%$ & 13 & $25.5 \%$ & 4 & $7.8 \%$ & 3 & $5.9 \%$ \\
\hline
\end{tabular}

\section{Discussion}

\subsection{Students' motivation to participate in webinars}

Respondents' answers to the question of the corresponding block of the questionnaire (Table 1-3) indicate the existence of two main groups of motives.

The biggest and most active part of the webinars audience consists of the respondents who agreed with the statements "I participate in webinars to get the information which is not given in the textbook" and "I participate in webinars to better understand the material". This position means a high level of independence and readiness to the perceive material that goes beyond the educational literature and creates the opportunity for the teacher's scientific search in an online audience. It should be noted that the total number of respondents in both of these groups is quite high and constitutes $56.9 \%$ of the respondents.

However, $43.1 \%$ of the respondents agreed with the statement that they attend webinars to have the necessary materials for the exam preparation. In other words, they consider the webinar to be the preferred source of knowledge when preparing for practical exercises and examinations, which indicates a low level of readiness for independent mastery of the course content, acquaintance with additional literature and the perception of problematic material, as required by the sciences teaching program at a modern university. At the same time, the problem-rich material of the webinar should be perceived as an obstacle to the acquisition (memorization) of the webinar content and its subsequent clear reproduction in a practical lesson.

\subsection{Quality assessment of the webinar materials by the respondents}

The second block of the questionnaire (the assessment block) includes questions 4-5.

While answering the question "Evaluate the following statements about the level of webinars in Philosophy you listened to", students had the opportunity to evaluate such aspects of webinar work as content, interestingness, understandability and evaluate the overall level of webinars they have listened to. It should be noted that the agreement/disagreement with the statement "I am satisfied with the overall level of webinars on Philosophy I listened to" can be considered an integral, most significant indicator of students' attitude to webinars.

A significant prevalence of positive ratings for all the proposed indicators can be observed. In particular, the satisfaction rate with the overall level of webinars, in general, was $78.4 \%$ of the respondents $(35.3 \%$ answered "Yes", 43.1\% answered "Rather yes than no"), with $15.7 \%$ and $5.9 \%$ of respondents who found it difficult to answer and who gave negative evaluation respectively.

Answers to other points of this question allow us to conclude that there are some opportunities for improving webinars. Considering the highest (compared with other indicators) assessment level of the content of webinars (90.2\% of respondents, of which $54.9 \%$ answered "Yes" and 35.3\% answered "Rather yes than no") and significantly low assessment level of the interestingness of webinars (overall positive assessment was $72.6 \%$, while a quarter of the respondents were unable to formulate a clear answer to this question), we can state the presence of imbalances between the quality of the webinar material and the expressive tools used by teachers in their work.

In general, the respondents positively assessed how webinars on Philosophy influence their professional and personal characteristics. More than $60 \%$ of the respondents approved the impact of learning Philosophy on the development of the conceptual and categorical apparatus, 
which is extremely important in terms of the formation of a future specialist and scientist (respondents indicated both positive quantitative and qualitative changes). About $60 \%$ of the respondents indicated that webinars on Philosophy helped to develop the discipline of their thinking and awareness of the importance of methodology in the development of scientific knowledge. However, only $46.9 \%$ agreed that they acquired knowledge that would be useful to them in their future professional and scientific activities. Analysis of the answers shows that teachers should pay more attention to the philosophical analysis of social processes taking place in the modern world.

As the webinar work of teachers of the Department of Philosophy is shown, the webinar technology requires minimal material and technical resources both for the teacher and for the participants. No additional software installation is needed, besides a web application. Platforms for webinars have an intuitive interface, convenient to configure for each participant, supporting operational feedback and the ability to exchange files. A great number of such platforms are provided by their developers for free and can be used by educational organizations.

Depending on the particular software platform, the webinar may have the following features and functional peculiarities [27-31]:

1. Holding audio and video conferences with different quality of video and simultaneous broadcasting by several participants.

2. Instant messaging using text chat. In this case, it is possible to use both the general chat, when all participants see all messages, and private communication between two persons with the ability to block the incoming messages.

3. Demonstration of electronic resources of various formats: presentations, documents, web pages, videos.

4. File exchange between webinar participants, downloading and uploading files of any size.

5. Teamwork with software. Any webinar participant with the appropriate rights (usually a teacher) demonstrates to all other participants the work in a specific software on the computer screen. At the same time, the teacher has the opportunity to transfer program management rights to any student with a specific task.

6. Web tours. A tool for sharing web sites. Besides, the facilitator can send participants web page addresses for independent viewing in their browser.

7. Survey and testing of webinar participants and instant visualization of the results using various charts.

8. Whiteboard. An electronic panel that functions as a collaboration board and has a standard set of tools: line, circle, square, etc.

9. Breakout rooms. Virtual rooms for working with groups. As a rule, these rooms are equipped with means of teamwork with text, video materials and multimedia presentations.

10. The function "Raising the hand" allows a participant of the webinar to draw the attention of the teachers and ask them to turn on the microphone, camera or other functionality. In a separate window of the facilitator, the names of the participants who "raised their hand" appear in the corresponding order.

11. The ability to print or save to the disk the materials of the webinar during the process.

12. The presence of a separate part of the virtual class to place the plan of the webinar. This plan is visible to all the participants, and its particular points may be noted in the process of their implementation.

13. The ability of the participant to identify emotions (in particular consent, objections, etc.) with the help of special indicators, which to some extent make up for the lack of direct contact.

14. Webinar recording for future use and analysis.

In addition to these functional features that can be implemented during the virtual lesson, most software platforms allow one to automate the preparation for the webinar, in particular, to register the participants, receive statistics and inform the participants about the event via e-mail.

\section{Conclusion}

Thus, the webinar technology has significant didactic capabilities and provides functionality sufficient for university students to learn collaborately, which can improve the acquisition of educational material, in particular as a part of teaching Humanities. The vast majority of traditional classes can be implemented using the webinar form. Undoubtedly, this form of organization of the educational process cannot completely replace traditional teaching, but it can significantly improve and upgrade the process of teaching Humanities.

It is worth mentioning that the practice of holding webinars to improve the educational process, first of all, diversify the learning process. Second, it stimulates the active independent work of students. Third, it increases their intellectual development. Fourth, it expands the possibilities of conducting consultative classes. Fifth, it ensures the development of a permanently changing information base, taking into account the requirements of modern society. Sixth, it ensures the efficient use of budget funds.

The results of the conducted sociological research demonstrated the existence of two main groups of motives for students' participation in webinars on philosophy: obtaining information on a topic that is not in the textbook and a better understanding of the topic material. This indicates a high level of student independence and readiness to perceive material that goes beyond the 
educational literature.

When assessing the quality of webinars, most of the students were satisfied with their general level, while the content aspect of the webinars was assessed higher than their interest, which indicates the lack of expressive means during their creation. In general, the respondents positively assessed the impact of philosophy webinars on the development of their professional and personal characteristics.

The results of the study confirmed the hypothesis that students' motivation to participate and attitudes to webinars are generally positive. At the same time, the results of the questionnaire of Humanities students indicate the need to develop methodological recommendations and instructional materials to promote the use of webinar technology, which is the prospect of further research.

The results of the study can be used when organizing webinars at a humanities university.

\section{Acknowledgments}

The publication was prepared with the support of the "RUDN University Program 5-100".

\section{REFERENCES}

[1] S. M. Duisenova, B. N. Kylyshbaeva, K. A. Avsydykova, Ye. Kh. Ishanov. Sociological Analysis of Educational Strategies in the System of Higher Education in Kazakhstan, Space and Culture, India, Vol. 7, No. 4, 181-193, 2020.

[2] G. M. Gogiberidze, V. A. Isakov, T. V. Ershova, O. V. Shulgina. Development of innovations in the educational environment: inclusive education and digital technologies, Revista Inclusiones, Vol. 7, Número Especial Abril/Junio, 147-158, 2020.

[3] J. J. H. G. De Velazco, A. C. C. Hernández. Una discusión epistemológica sobre gestión de la participación ciudadana. Opción, Vol. 34, No. 87, 856-883, 2018.

[4] T. K. Rostovskaya, A. S. Maksimova, N. M. Mekeko, S. N. Fomina. Barriers to Students' Academic Mobility in Russia, Universal Journal of Educational Research, Vol. 8, No. 4, 1218-1227, 2020.

[5] A. D. Matraeva, M. V. Rybakova, M. V. Vinichenko, A. A. Oseev, N. V. Ljapunova. Development of Creativity of Students in Higher Educational Institutions: Assessment of Students and Experts, Universal Journal of Educational Research, Vol. 8, No. 1, 8-16, 2020.

[6] T. I. Golubeva, I. I. Kokhanovskaya, E. V. Golovneva, A. L. Fatykhova, N. V. Terekhova. Social Networks and Education: the Increase in Student Learning Efficiency and the Search for Means of Control, Revista Inclusiones, Vol. 7, Número Especial. Julio - Septiembre, 48-60, 2020.

[7] I. K. Ficheman, R. de Deus Lopez. Digital Learning Ecosystems: Authoring, Collaboration, Immersion and
Mobility, Eighth IEEE International Conference on Advanced Learning Technologies. IEEE Computer Society, Santander, Spain, 371-372, 2008.

[8] S. K. Basak, M. Wotto, P. Belanger. E-learning, M-learning and D-learning: Conceptual definition and comparative analysis, E-Learning and Digital Media, Vol. 15, No. 4, 191216, 2018.

[9] N. M. Dugalich, N. V. Alontseva, Yu. A. Vasilieva, I. A. Rubannikova, M. I. Mikheeva, N. V. Kudryashova. Increasing efficiency of foreign-language teaching: gamification technologies in education, Revista Inclusiones, Vol. 7, Número Especial. Julio - Septiembre, 151-163, 2020.

[10] A. A. Sapfirova, V. V. Volkova, E. V. Khakhaleva, I. V. Kardanova. Gender Inequality in Russian Agriculture: Problems and Prospects of Legal Regulation, Journal of Advanced Research in Law and Economics, S. 1, Vol. 10, No. 6, 1741-1745, 2019.

[11] O. O. Jethro, A. M. Grace, A. K. Thomas. E-Learning and Its Effects on Teaching and Learning in a Global Age, International Journal of Academic Research in Business and Social Sciences, Vol. 2, No. 1, 203-210, 2012.

[12] S. Goyal. E-Learning: Future of Education, Journal of Education and Learning, Vol. 6, No. 2, 239-242, 2012.

[13] A. G. Sergeev, I. E. Zhigalov, V. V. Balandina. Vvedenie v elektronnoe obuchenie: monografiya [Introduction to E-Learning: A Monograph]. VlGU, Vladimir, 2012.

[14] G. V. Mozhaeva. Elektronnoe obuchenie v vuze: sovremennye tendentsii razvitiya [University E-Learning: current trends], Gumanitarnaya informatika [Humanitarian Informatics], Ed. 7, 126-138, 2013.

[15] S. A. Kornienko. Elektronnoe obuchenie kak sredstvo realizatsii obrazovatelnoi programmy [E-learning as a means of implementing an educational program], Pedagogika: traditsii i innovatsii [Pedagogy: traditions and innovations]: materials from $\mathrm{V}$ international scientific conference. Chelyabinsk, 175-182, 2014.

[16] D. R. Knapczyk, T. J. Frey, W. Wall-Marencik. An evaluation of web-conferencing in online teacher preparation, Teacher Education and Special Education, Vol. 28, No. 2, 51-61, 2005.

[17] V. A. Slepov, T. N. Rodenkova, M. E. Kosov, A. I. Grishin. Human Capital Development as an Element of Financial Management in National Education Systems, Journal of Advanced Research in Law and Economics, S. 1, Vol. 10, No. 4, 1303-1308, 2019.

[18] S. Matveeva, N. Akatova, Y. Shcherbakov, N. Filinova. Digitalization of Higher Education and Professional Development of Educators: Technologies and New Opportunities, Amazonia Investiga, Vol. 9, No. 29, 77-86, 2020.

[19] S. Cornelius, C. Gordon. Facilitating learning with web conferencing recommendations based on learners' experiences, Education and Information Technologies, Vol. 18, 275-285, 2013.

[20] K. Kear, J. Chetwynd Williams, H. Donelan. Web conferencing for synchronous online tutorials: Perspectives 
of tutors using a new medium. Computers \& Education, Vol. 58, 953-963, 2012.

[21] N.-S. Chen, H.-C. Ko, Kinshuk, T. Lin. A model for synchronous learning using the Internet, Innovations in Education and Teaching International, Vol. 42, No. 2, 181-194, 2005.

[22] W. P. McKinney. Assessing the evidence for the educational efficacy of webinars and related internet-based instruction, Pedagogy Health Promotion: The Scholarship of Teaching and Learning, Vol. 3, 475-515, 2017.

[23] R. Polanco-Bueno. Blogs, webinars and significant learning: A case report on a teacher training program for college teachers, Higher Learning Research Communications, Vol. 3, No. 1, 56-67, 2013.

[24] S. K. Wang, H. Hsu. Use of the webinar tool (Elluminate) to support training: The effects of webinar-learning implementation from student-trainers' perspective, Journal of Interactive Online Learning, Vol. 7, No. 3, 175-194, 2008.

[25] M. Power, A. St-Jacques. The Graduate Virtual Classroom Webinar: A Collaborative and Constructivist Online Teaching Strategy, MERLOT Journal of Online Learning and Teaching, Vol. 10, No. 4, 681-696, 2014.

[26] D. R. Garrison. Online collaboration principles, Journal of
Asynchronous Learning Networks, Vol. 10, No. 1, 25-34, 2006.

[27] A. Gegenfurtner, A. Zitt, C. Ebner. Evaluating webinar-based training: a mixed methods study of trainee reactions toward digital web conferencing, International Journal of Training and Development, Vol. 24, No. 1, 5-21, 2020.

[28] G. Guanci. Best practices for webinars, Creative Nursing, Vol. 16, 119-121, 2010.

[29] A. T. Black, M. Clauson, S. Fraser. Nursing education and research rounds: Evaluation of a webinar-based education strategy to engage nurses and support practice, Journal for Nurses in Professional Development, Vol. 29, 249-254, 2013.

[30] J. D. Martin-Smith, A. McArdle, S. M. Carroll, E. J. Kelly. Webinar: A useful tool in plastic surgery specialty trainee education, Journal of Plastic Reconstructive \& Aesthetic Surgery, Vol. 68, 1323-1324, 2015.

[31] A. S. Kagasyan, N. D. Kotovchikhina, I. V. Poshentseva, T. L. Kashchenko, E. V. Aralova. Technologies and tools to improve the quality of university education, Revista Inclusiones, Vol. 7, Número Especial. Julio - Septiembre, 566-578, 2020. 